\title{
IMPROVEMENT OF THE EFFICIENCY OF PERENNIAL SEED MIXTURES SEPARATION ON A DRUM VIBRO ELECTRIC SEPARATOR
}

\author{
Stepan Kovalyshyn ${ }^{1}$, Oleksanda Kovalyshyn ${ }^{2}$ \\ ${ }^{1}$ Faculty of Mechanics and Power Engineering, Lviv National Agrarian University, Ukraine \\ ${ }^{2}$ Land ManagementFaculty, Lviv National Agrarian University, Ukraine
}

To cite this article: KOVALYSHYN STEPAN, KOVALYSHYN OLEKSANDA. 2018. Improvement of the Efficiency of Perennial Seed Mixtures Separation on a Drum Vibro Electric Separator. Acta Universitatis Agriculturae et Silviculturae Mendelianae Brunensis, 66(5): 1157-1164.

To link to this article: https://doi.org/10.11118/actaun201866051157

\begin{abstract}
Separation of seed mixtures plays a very important role in obtaining high-quality seeds, which is characterized by the absence of hard-to-separate admixtures of weeds. The aim of the work was to improve the quality of seed mixtures of perennial grasses due to the use of the drum separator in the process of their additional cleaning.

The conducted studies determined the basic geometric dimensions of the components of seed mixtures of perennial grasses and their coefficients of friction on various materials. The difference in their values was insignificant, as a result of which it was found that separating by these indicators is inappropriate. We can intensify the separation of the studied mixtures by using a drum vibro electric separator, where the separation takes place in a combination of frictional and electrical properties of the components.

The main adjustable parameters of vibro electric separation established by previous studies were: the drum speed $f=8 \mathrm{rpn}$; the electric field of corona discharge $E=3.0 \mathrm{kV} / \mathrm{cm}$; the oscillation frequency of the drum $f_{1}=50 \mathrm{~Hz}$; drum amplitude $A=1,6 \mathrm{~mm}$. With such parameters of separation we achieved the purity of the seed of the clover and the timothy grass in the range of $97 . . .98 \%$, which, respectively, for $22.5 \%$ and $17.5 \%$ exceeds the purity of the original mixture.
\end{abstract}

Keywords: perennial grasses, seed mixtures, hard-to-divide impurities, separation process, vibro electric frictional separator, adjustable parameters, seeds' purity

\section{INTRODUCTION}

Cleaning and sorting of perennial grasses seed mixtures is implemented by using different technologies of postharvest handling and technical means (Bartneev et al.., 2013; Buhaiov, 2012; Druncha et al., 2010). However, seed separating machines, in most cases, do not provide the prescribed quality of cleaning, that is why they can not obtain the sowing seed material that would meet the requirements of existing standards
(Ukrainian State Standards, 2010). This is primarily due to the presence of hard-to-divide of weeds and all sorts of injured seeds. These impurities are not significantly different in the basic physical, mechanical and aerodynamic properties of seeds of cultivated plants, through which the process of separation is hampered.

To avoid these shortcomings and improve the efficiency of separation of seed mixtures of grasses we must implement a series of measures aimed at improving their postharvest processing. 
These measures should include: deep study of the physical and mechanical, aerodynamic, electrical and other properties of seed mixtures of perennial grasses components; to identify, through research, the properties of new features of divisibility; improvement and development of the working bodies of the separators, which could ensure the separation of mixtures of perennial grasses due to the new features of divisibility (Ch'ng et al., 2013; Kovalyshyn et al.., 2014; Molenda et al., 1995; Molenda et al.., 2000; Tarasenko et al.., 2009; Zaika, 2006; Zare et al., 2013).

Nowadays, the most common technology of postharvest handling of seed mixtures provides primary, secondary and additional treatment. For the seeds of perennial grasses the most important step is the very additional treatment .

In order to increase the efficiency and achieve the seed material which would meet the requirements of existing standards, we must provide the seed cleaning machines with as an additional working body - electric field (Kovalyshyn et al., 2013; Tarushkin, 1987). Electric separation is based on the interaction of charged particles of a seed mixture with a working body of the separator. Because weed seeds and cultivated plants ones belong to different species, their electrical properties are different. So they will get a different charge and different ways to interact with the working body of the separator. Under these conditions, we can expect a positive result from the process of separation of hard-to-divide impurities and various mixtures of damaged seeds of perennial grasses.

Promising in terms of additional cleaning of perennial grasses is the use of drum separators. To create their advanced design is possible by the use of superposition of forces principle of different physical nature (Kovalyshyn et al., 2014; Kovalyshyn et al., 2013). We can achieve this in condition of the cumulative effect on the particles of seed mixtures of vibrations, electric field strength, gravitational forces and so on (Tarushkin, 1987). But separation under such conditions, especially in the working cylinder bodies, are not studied properly enough and requires theoretical and experimental studies.

\section{MATERIALS AND METHODS}

In order to determine the effectiveness of separation in the drum separator we studied seed mixtures of the most common perennial legume grass - clover and its hard-to-divide impurities - English plantain (Plantago lanceolata) and horse sorrel (Rumex confertus), and grasses - timothy-grass (Phleum pratense) and its main impurity - scentless mayweed (Tripleurospermum inodorum).

The study included: assessment of the external surface using photographs taken at the electron microscope; identification of key physical and mechanical properties of cultivated seeds and weeds; establishing the degree of pollution of grasses seed mixtures in the original and in separated fractions; determining the effectiveness of electric separation.

Assessment of the state of the outer surface of the studied seeds of cereals, legumes and weeds were performed by analyzing their photographs. These photographs were taken on an electronic scanning microscope (SEM) JEOL-T220A. When taking a picture using the increase from 35 to 50 times. Preparing the samples for research in the SEM included two procedures - fixation and metallization of the sample's surface. Due to the SEM photographes we obtained images of the studied grass seeds that allow us to evaluate the state of the surface, damages, detect the characteristic morphological features that distinguish the possibility of separation.

Basic geometric parameters - length, width, thickness were measured using bilateral caliper SHTS-1; friction properties - internal and external coefficients of friction on steel, metal foil, glass, thick canvas - belting and coefficient of internal friction - the Jenike's device; 1000 seeds weight - on an analytical balance WA-31.

Coefficients of external friction and of the angle of internal friction of seeds of the examined groups were determined on glass, steel, aluminium, and belted surfaces.

The determinations were made with the use of the Jenike apparatus (Fig. 1) in conformance with the method recommended by (European committee for standardization, 2006).
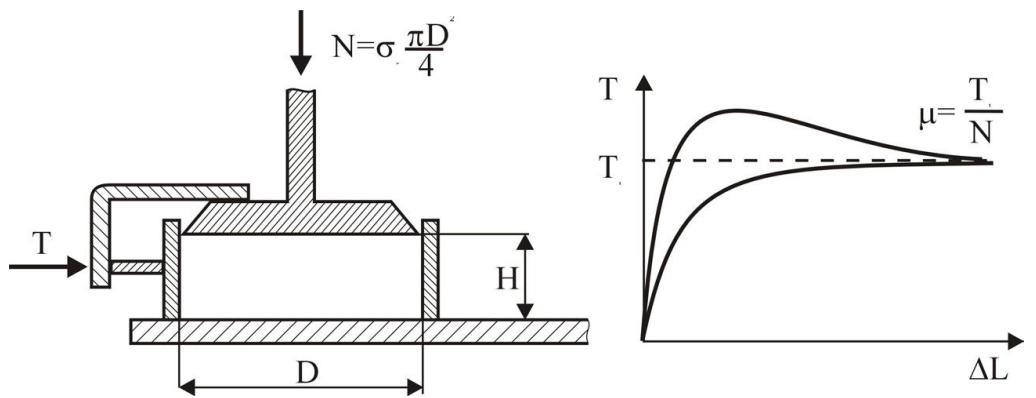

1: Schematic diagram of experimental procedure for determination of the wall friction coefficient ( $\mu$ ) according to (European committee for standardization, 2006). $N$ - consolidation stress ( $k P a), T, T_{1}$-shear stress obtained for two different values of consolidation stress ( $\left.k P a\right)$, $H$-height of the probe in direct shear tester $(\mathrm{mm}), L$-displacement of upper ring of tester during measurement (mm) 
The principle of operation of the Jenike apparatus consists in recording the force of the movement of two rings relative to each other in the horizontal plane. A consolidated sample is placed in the chamber composed of two rings.

The Eurocode 1 standard recommends that the strength parameters of a granular material: the angle of internal friction $\varphi$, effective angle of internal fraction $\delta$ and cohesion $c$ should be determined in the Jenike apparatus according to a simplified procedure including preliminary consolidation and shearing of the sample (Fig. 2). The strength para-meters of a granular material should be determined on the basis of two separate tests performed in accordance with the procedure: one sample consolidated and sheared at normal stress $\sigma_{r}$ and a second sample, consolidated at reference pressure $\sigma_{r}$ and then sheared at normal stress $1 / 2 \sigma_{r}$.

The diameter (D) of the shear chamber should be at least 40-fold larger than the maximum dimension of a single kernel of the sample studied, and height $\mathrm{H}$ should be within the range of 0.3-0.4D.

For the experiments with the division of the bulk of clover and timothy-grass weeds and their hard-to-divide additives we used an advanced design of drum vibro electric separator, it's structure and technological scheme of work is presented in Fig. 3.

The proposed vibro electric separator works as follows. From the supply bunker 1 the seed mixture using a rotating roller 2 with pits (not indicated in the figure) is fed to a parabolic ramp conductive plane 4 , which has a grounding pin 5 . The parabolic shape of ramp 4 is selected due to the speeds control of the cultivated seeds and seeds of their impurities in their admission to the zone of the electric field of the space charge. Such speed regulation should provide their maximum difference. Such speed difference together with the difference in electric charge of the cultivated culture seeds and seeds of the impurities are formed by the electric field on

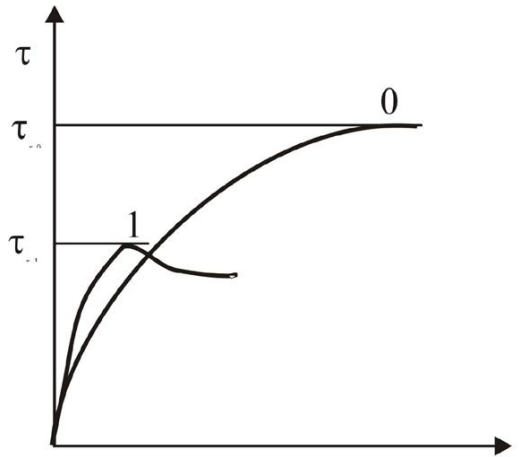

$\Delta \mathrm{L}$

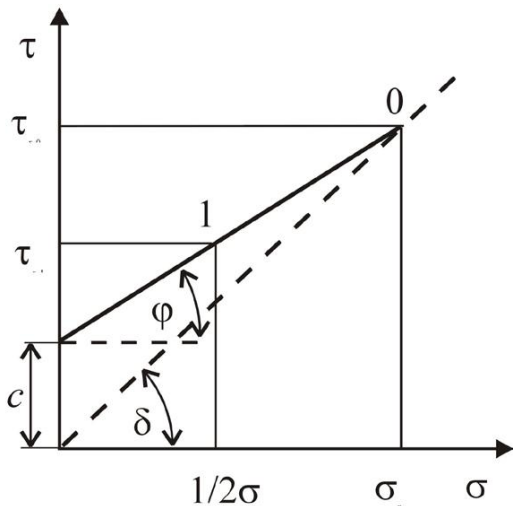

$1 / 2 \sigma$

2: Determination of shear strength parameters according to (European committee for standardization, 2006). $\tau$-shear stress ( $k P a$ ), $\tau_{r 0}$-shear stress obtained for consolidation stress $\sigma_{r}(k P a), \tau_{r 1}$-shear stress obtained for consolidation stress $1 / 2 \sigma_{r}(k P a), \varphi$-angle of internal friction, $\delta$-effective angle of internal fraction

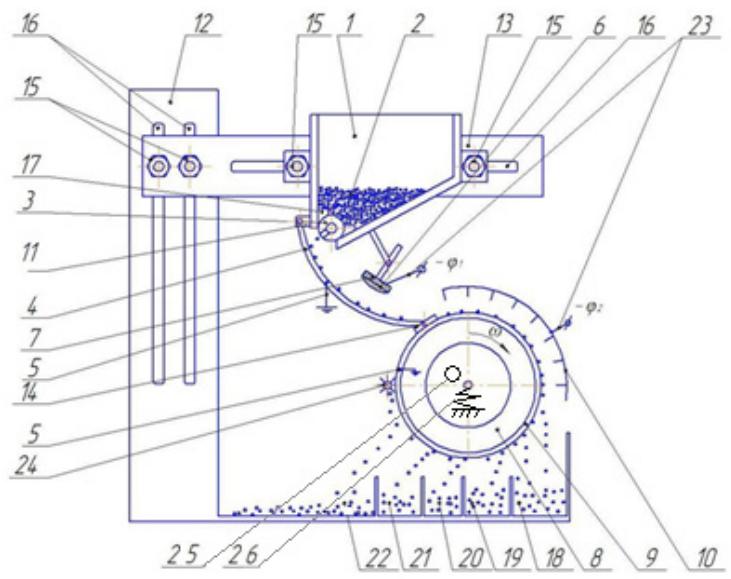

3: Scheme of electric crown drum separator

1-supply bunker; 2 - small seeded mixture; 3 - drum shaft assembly; 4 - inclined parabolic plane; 5 - grounding pin; 6 - flat potential electrode; 7 - dielectric bracket; 8 - drum; 9 - smooth electrical surface; 10 - crowning coaxial needle electrode; 11 - dielectric bracket; 12 - frame; 13 - horizontal beam; 14 - bracket; 15 - bolts with nuts; 16 - vertical slit; 17 - elastic dielectric laying; 18 - 22 receiving cells; 23 - high conductive wireless connection; 24 - broom; 25 - vibration exciter; 26 - spring 
the inclined parabolic plane 4, which is created by the potential electrode 6 as a conductive plate attached to the dielectric bracket 7 .

Having obtained negative in sign and magnitude different electric charges, the weed seeds and seeds of cultivated plants are coming down at different speeds from the plane 4, they get into separating rotating drum 8 which has a smooth grounded 5 conductive surface 9.

Drum spindle is fixed by two springs 26. One side of the drum has vibration exciter 25 which has a separate drive (not shown on diagradm). Mentined vibration exciter provides possibility to perform drum bibrations.

Over the drum 8 coaxially to its surface a crowning needle electrode 10 is installed. This electrode generates an electric corona discharge, resulting that the seeds arrived on the surface of the drum, in addition to already existing their electric charge, are dynamically charged with negative ions which are generated in the interelectrode airspace by the electrode needles 10 under the influence of their high potential. Seeds with different kind of damages or explicit grooves or sharp edges are receiving its greater value because the ions are concentrated precisely on these areas. Thanks to this they are strongly pressed by the electric field to electrically conductive plane of the drum and with it are moved to the waste receiver $20-22$.

Quality seeds get smaller charge because their surface is smoother and without defects, they are less attracted to the surface of the drum, resulting that they fall in the course into the first receiver 18.
The proposed drum vibro electric separator's main adjustable parameters that affect the quality of separation were: speed of the drum ( $f$, rpn), the electric field of corona discharge $(E, \mathrm{kV} / \mathrm{cm})$, the oscillation frequency of the drum $\left(f_{1}, \mathrm{~Hz}\right)$ and its amplitude $(A, \mathrm{~mm})$.

\section{RESULTS}

The possibility of effective separation of hard-to-divide grass seed mixtures of weed impurities and various damaged seeds was established on the basis of experimental data of their morphological features and characteristics, physical and mechanical properties, the range of these properties' changes etc. Summarizing the data, we can find some new signs of divisibility, improve and develop operational structure of separators that ensure separation on these grounds.

The evaluation of morphological characters of the studied seed varieties of perennial grasses and their hard-to-divide impurities made based on the analysis of electronic pictures of their surfaces (Figs. 4...5).

By the results of this analysis we can state that as part of the seed mixture of clover we find seeds of hard-to-divide impurities - English plantain and horse sorrel (Fig. 4b, 4c). By the external signs of hard-to-divide seed impurities we have certain similarities with signs of clover seed. All of them are dark brown; ellipsoid-shaped; bulging. However, they present some differences. English plantain seeds are more elongated. On one of its sides, along

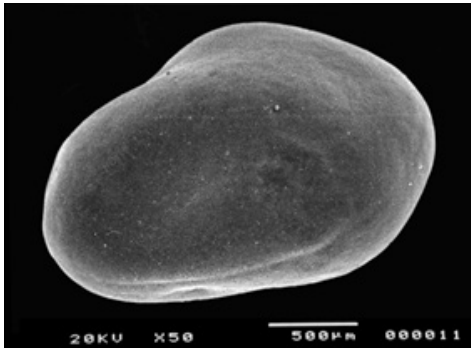

a)

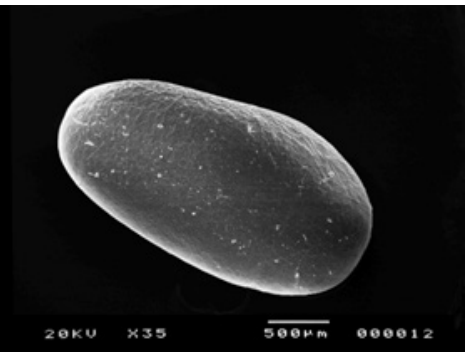

b)

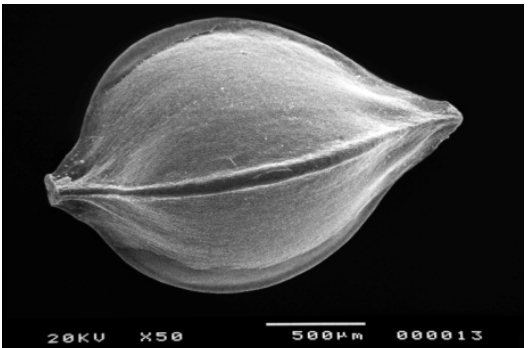

c)

4: Electronic photos of the outer surface of the seeds of the legume grasses - clover (a) and its hard-to-divide impurities - plantain lanceolate (b) and horse sorrel (c)

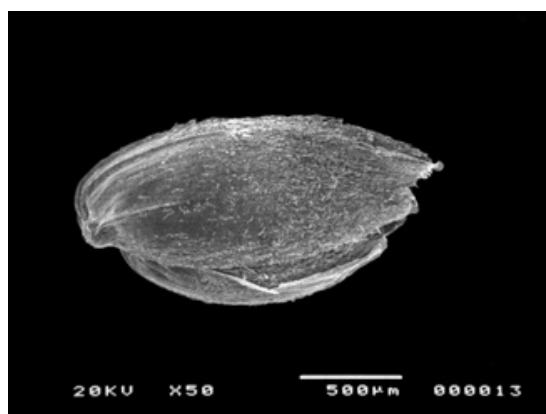

a)

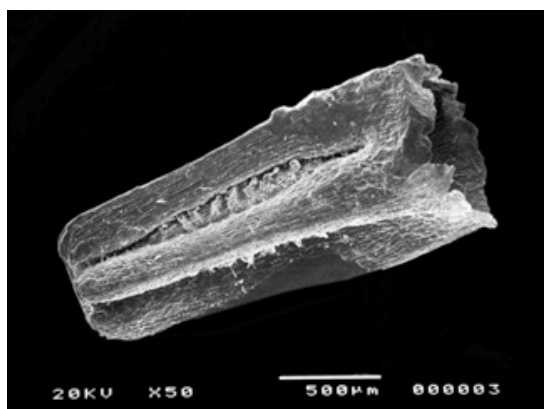

b)

5: Electronic pictures of the outer surface of the seeds of the cereal grasses of timothy-grass (a) and its main impurity-scentless mayweed (b) 
the entire length there is a small groove (Fig. 4b). Horse sorrel seed has well-seen three sharp edges (Fig. 4c).

Observation of timothy-grass seeds and its impurity - scentless mayweed seeds pictutes demonstrates some differences of their forms. The timothy-grass seeds are rounded (Fig. 5a) and scentless mayweed seeds are characteristicly elongated with three ribs (Fig. 5b).

These morphological features form the basic precondition in the choice of technical means to separate these mixtures of perennial grasses. In this case, we are to use electric separators that as additional working body operates with an electric field of corona discharge. It is in the grooves or on sharp edges of seeds during electric separation where the ions will concentrate, resulting that hard-to-divide impurities will get stronger charge and will gravitate to the working surface of the separator much more than the grass seed. As a result, they will move on the surface of the working body on different trajectories, which is the main precondition for their effective separation.

The results of studies of physical and mechanical properties of the investigated grass seeds and and their hard-to-divide impurities weeds seeds are shown in Tab. I.

Shown in Tab. I dimensional characteristics analysis showed that the difference components of the studied seed mixtures in length, width and thickness are insignificant. This indicates that to separate English plantain and horse sorrel, and grasses - timothy-grass and its main impurity - scentless mayweed by size is not advisable and possible.

Determined coefficients and angles of friction of the studied cultivated seeds and their impurities suggest the following. Values for friction angles of the studied seeds of grasses and weeds on glass, steel and aluminum foil are almost the same and make $12-15^{\circ}$. Based on this we can conclude that out of clover and timothy-grass seeds we can not distinguish the studied hard-to-divide impurities in a separator, where as working body the friction surfaces are used.

The exception is the angle of external friction of timothy-grass and its main impurity - scentless mayweed on aluminum foil. The difference angle value for these components makes $8^{\circ}$, which confirms the possibility of their effective separation on the friction surface, based on aluminum foil.

Summing up the values of physical and mechanical properties of the studied species of perennial grasses and their hard-to-divide impurities we can state that use of friction working bodies of seed separating machines or sieves for separating them is impractical. The reason for this is the inability to use the form, geometric dimensions, surface condition of a mixture as a sign of divisibility.

I: Physical and mechanical properties of perennial grasses' seeds and their hard-to-divide impurities

\begin{tabular}{|c|c|c|c|c|c|c|c|c|}
\hline \multirow[b]{2}{*}{ Grasses } & \multicolumn{3}{|c|}{$\begin{array}{l}\text { Ratio/angle of external } \\
\text { friction, degree }\end{array}$} & \multirow{2}{*}{ 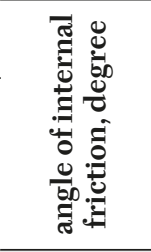 } & \multirow{2}{*}{ 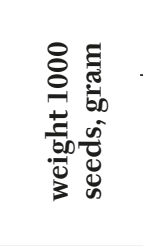 } & \multicolumn{3}{|c|}{ Geometrical dimensions, mm } \\
\hline & $\frac{\mathscr{y}}{0}$ & 总 & 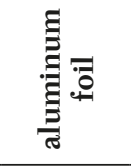 & & & 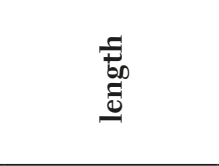 & $\frac{5}{\frac{5}{0}}$ & 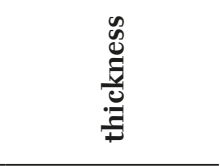 \\
\hline Clover & $\begin{array}{c}0.258 / \\
14 \pm 3 \%\end{array}$ & $\begin{array}{c}0.217 / \\
12 \pm 1.8 \%\end{array}$ & $\begin{array}{c}0.246 / \\
13 \pm 2.1 \%\end{array}$ & $29.1 \pm 4 \%$ & $1,7 \pm 1.2 \%$ & $(1.5 \ldots 2.2) \pm 2 \%$ & $(0.7 \ldots 1.2) \pm 2.4 \%$ & $(1.1 \ldots 1,7) \pm 2.8 \%$ \\
\hline Tymothy-grass & $\begin{array}{c}0.223 / \\
12 \pm 5 \%\end{array}$ & $\begin{array}{c}0.213 / \\
12 \pm 2.8 \%\end{array}$ & $\begin{array}{c}0.230 / \\
13 \pm 2.1 \%\end{array}$ & $31.5 \pm 4.1 \%$ & $0,6 \pm 3.2 \%$ & $(1.3 \ldots 2.1) \pm 2.5 \%$ & $(0,6 \ldots 0,9) \pm 1.2 \%$ & $(0,7 \ldots 0,9) \pm 2.1 \%$ \\
\hline Horse sorrel & $\begin{array}{c}0.242 / \\
13 \pm 1.3 \%\end{array}$ & $\begin{array}{c}0.232 / \\
13 \pm 1.6 \%\end{array}$ & $\begin{array}{c}0.237 / \\
13 \pm 3.1 \%\end{array}$ & $28.3 \pm 1.5 \%$ & $0,7 \pm 1.2 \%$ & $(1.8 \ldots 2.4) \pm 1.9 \%$ & $(0.9 \ldots 1,5) \pm 1.5 \%$ & $(0.9 \ldots 1.3) \pm 1.3 \%$ \\
\hline $\begin{array}{l}\text { English } \\
\text { plantain }\end{array}$ & $\begin{array}{c}0.231 / \\
13 \pm 0.7 \%\end{array}$ & $\begin{array}{c}0.219 / \\
12 \pm 1.3 \%\end{array}$ & $\begin{array}{c}0.242 / \\
13 \pm 2.7 \%\end{array}$ & $27.2 \pm 2.2 \%$ & $0,8 \pm 1.5 \%$ & $(1.0 \ldots 2.5) \pm 1.5 \%$ & $(0.9 \ldots 1.2) \pm 2.1 \%$ & $(0.7 \ldots 1.0) \pm 1 \%$ \\
\hline $\begin{array}{l}\text { Scentless } \\
\text { mayweed }\end{array}$ & $\begin{array}{c}0.273 / \\
15 \pm 2.9 \% \\
\end{array}$ & $\begin{array}{c}0.260 / \\
14 \pm 1.7 \% \\
\end{array}$ & $\begin{array}{c}0.268 / \\
5 \pm 2.5 \% \\
\end{array}$ & $36.8 \pm 2.7 \%$ & $0,5 \pm 1.7 \%$ & $(1.5 \ldots 2.5) \pm 1.8 \%$ & $(0.7 \ldots 1.2) \pm 2.5 \%$ & $(0.5 \ldots 0.7) \pm 2.8 \%$ \\
\hline
\end{tabular}

$\pm \%$ - mean square deviation of the studied parameters

II: Results vibro electric separation of seed mixtures of perennial grasses in drum separator

\begin{tabular}{|c|c|c|c|c|c|c|c|}
\hline \multirow[b]{2}{*}{$\begin{array}{c}\text { Type of } \\
\text { perennial } \\
\text { grasses }\end{array}$} & \multicolumn{4}{|c|}{ Seed purity, $\%$} & \multicolumn{3}{|c|}{$\pm / \%$ before initial material } \\
\hline & $\begin{array}{l}\text { Initial } \\
\text { mixture }\end{array}$ & $\begin{array}{l}\text { Separation } \\
\text { на барабані }\end{array}$ & $\begin{array}{c}\text { Electric } \\
\text { separation } \\
\text { in a drum }\end{array}$ & $\begin{array}{c}\text { Electric } \\
\text { vibro } \\
\text { separation } \\
\text { in a drum }\end{array}$ & $\begin{array}{l}\text { separation } \\
\text { in a drum }\end{array}$ & $\begin{array}{c}\text { Electric } \\
\text { separation } \\
\text { In a drum }\end{array}$ & $\begin{array}{c}\text { Electric } \\
\text { vibro } \\
\text { separation } \\
\text { на барабані }\end{array}$ \\
\hline Clover & 74.5 & 78 & 86 & 98 & 3.5 & 6.5 & 23.5 \\
\hline
\end{tabular}


In order to intensify the separation process of the studied mixtures it is advisable to use a drum separator (Fig. 1), in which on the top of the aluminum cylindrical surface we impose an electric field of corona discharge.

The first results of the studied separation of mixtures of herbs in the separator testify its effectiveness (Tab. II). The main adjustable parameters of vibro electric separation established by previous studies were: the drum speed $f=8 \mathrm{rpn}$; the electric field of corona discharge $E=15 \mathrm{kV} / \mathrm{cm}$; the oscillation frequency of the drum $f_{1}=50 \mathrm{~Hz}$; drum amplitude $A=1,6 \mathrm{~mm}$.

Seed purity, separated from the mixture, is characterized by the content of hard-to-divide impurities and having been purified on a drum vibro electric separator increased comparedly with the original mixture to $11.5 \%$ and amounted as for clover to $86 \%$, and timothy-grass - $88 \%$. Much more higher the seed purity value is reached when to the surface of the drum we impose an electric field of corona discharge of vibration fluctuations. Under these conditions, the purity of clover seeds or timothy-grass ones make $97 . . .98 \%$, which is by $22.5 \%$ and $17.5 \%$ higher than the purity of the initial mixture.

\section{DISCUSSION}

Hard-to-divide impurities of seed-bearing material of perennial grasses are separated in seed clearing machines intended for additional purification. A significant part of them is electromagnetic machines, in which the separation is based on the interaction of a magnetic field with a magnetic powder deposited on the surface of the seeds (Ciobanu, et al., 2017; Karpin, et al., 1993; Yunuson, et al., 2001 ). However, in many cases, the use of electromagnetic seed cleaning machines does not give the desired result, as the components of herbal mixes differ a little in roughness, which prevents them from applying a magnetic powder of varying intensity. On the other hand, this method is costly and negatively affects the environment.

Another niche of additional cleaning are air-grid-trieer machines, which work in the grain-cleaning complexes KOC-0,5, KOC-0,5M and KOC-2 produced in Germany. However, the purification of sowing material of small-seeded crops is ineffective because of significant losses of the main culture in the waste (Buhayov, et al.., 2012; Kovalyshyn, 2013; Kolisnik, et al.., 2007).
For example, when cleaning seeds of perennial herbs is lost from 30 to $50 \%$ of their gross collection (Erk, 1981; Kovalyshyn, et al., 2016).

Somewhat better results of separation of seed mixtures of herbs are achieved when using friction and vibro-friction separators, in which the separation of components passes through their elastic properties, roughness and form of the seed surface (Zaika, et al., 1988). However, in most cases, these indicators of hard-to-divide impurities are almost the same as seed grasses, which greatly complicates the process of their separation.

Thus, it can be argued that the essential similarity of the basic physical and mechanical properties of seeds of perennial grasses and their heavily separated weeds is a major disadvantage that prevents effective separation (Ovsyannikova, et al.., 2009).

To increase the quality of sowing material of perennial grasses becomes possible by separating from it hard-to-divide seeds of weeds with the help of separators, in which the seeds are imposed to different natural forces - gravity, electric, forces of inertia. Separation in this case is carried out as a result of the selective aggregate action of these forces on the components of the separating mixture. It is precisely this principle that has been implemented in the drum vibro electric separator proposed in this paper. By optimizing its adjustable parameters - the speed of rotation of the drum, the tension imposed on it by the electric field of the corona discharge, the frequency and amplitude of oscillations, we can achieve a significant difference between the combined effect of these forces on the seeds of grass and hard-to-divide weeds. It is under such conditions that their separation is the most effective. This is confirmed by the results of purification of the seed material of the clover and the timothy grasses seeds on the proposed drum vibration electro-separator. They confirm that the purity of the seed material of these crops after cleaning on the content of hard-to-divide weed admixture is significantly higher than that of the initial mixture and corresponds to the existing standard (Ukrainian State Standards, 2010).

The obtained results can be used in the process of separation research on the drum vibro electric separator for other hardly separated seed mixtures. In addition, their practical value is also that they serve as source information for the development of technical and design documentation for the manufacture of drum vibration electro-friction separator.

\section{CONCLUSIONS}

1. Researches of geometric dimensions: weight of 1000 seeds, different angles of friction on friction surfaces of perennialgrasses seeds and their hard-to-divideimpuritiesindicateinsignificant differences of the obtained values, which also indicates some difficulties in the process of their separation.

2. In order to improve the quality of separation of seed mixtures of perennial grasses we can use vibro electric separators during their additional cleaning. Thanks to supplying their working bodies with selective force effect into components of seed mixtures a quality of their separation is observed. 
3. Preliminary experiments established that by use of drum vibro electric separators we achieve clover and timothy-grass seeds purity at $97 . . .98 \%$, thus meeting the requirements of existing standards for content of hard-to-divide impurities.

Acknowledgements

The presented work was performed in accordance with the research development "Development of new technologies and technical means for the preparation of small-seeded mixtures with the help of controlled electromagnetic actions" (state registration number: 0117 U 003081). Funded by the Ministry of Education and Science of Ukraine.

\section{REFERENCES}

BARTNEEV, I., DREPALIUK, M. and KIZAKOV, V. 2013. Technologies perfection and means of mechanization of reforestation [in Russian: Совершенствование технологии и средств лесовостановления]. Moscow: Flinta.

BUHAIOV, V., ANTONIV, D. 2012. Modern technologies of perennial grasses seeds' production [in Ukrainian: Сучасні технології виробництва насіння багаторічних трав]. Posibnyk ukrainskoho hliboroba, 21: 156-161.

CIOBANU, V., VISAN, A., PAUN, A. et al. 2017. Experimental research regarding magnetic separation of seeds after their surface conditions using moistening liquids. In: $16^{\text {th }}$ International Scientific Conference on Engineering for Rural Development, Latvia Univ Agr, 24-26 .05. 2017. Latvia: Latvia Univ Agr, pp. 1000-1005.

CH'NG, P., ABDULLAH, M., MATHAI, E. et al. 2013. Some physical properties of ginkgo nuts and kernels. International Agrophysics, 27(4): 485-489.

DRUNCHA, V., CUDENDORZIEV, B. and PAVLOV, S. 2010. Basic conceptual development position of seed preparation technology [in Russian: Основные концептуальные положения разработки технологий подготовки семян]. Hranenie i pererabotka zerna, 5(131): 36-38.

ERK, F. 1981. Problems of cleaning seeds of perennial grasses [in Russian: Проблемы очистки семян многолетних трав]. Engineering in Agriculture, 12: 14-18.

EUROPEAN COMMITTEE FOR STANDARDIZATION. 2006. Eurocode 1: Actions on structures - Part 1-7: General actions - Academic actions. EN 1991-7:2006 (E). Brussels: CEN.

KARPIN, V., GORSHKOV, G. and PEREPRAVO, N. 1992. Cleaning seeds of crops method [in Russian: Способ очистки семян сельскохозяйственных культур]. SU 1777684, Russia.

KOLISNIK, S., ANTONIV, S. and BORONA, V. 2007. How to get high quality seeds [in Ukrainian: Як отримати якісне насіння]. Seedling, 4: 5-17.

KOVALYSHYN, S. 2013. Scientific and methodological approaches for the preparation of sowing material of small-seeded crops [in Ukrainian: Науково-методичні підходи підготовки посівного матеріалу дрібнонасіннєвих сільськогосподарських культур]. Interagency thematic scientific collection "Mechanization and electrification of agriculture", 97(1): 387-393.

KOVALYSHYN, S. and DADAK, V. 2013. Friction coefficient researches of small seeded crops [in Ukrainian: Дослідження коефіцієнта тертя насіння дрібнонасіннєвих сільськогосподарських культур]. Visnyk Lvivskoho natcionalnoho ahrarnoho universytetu «Ahroinzenerni doslidzennya», 17: 155-164.

KOVALYSHYN, S. and DADAK, V. 2014. Separation efficiency enhancement of forage perennial grasses' seeds [in Ukrainian: Підвищення ефективності пневмосепарування насіння кормових трав]. Visnyk Harkivskoho nacionalnoho tehnichnoho universytetu im. Petra Vasylenka: Tehnichni systemy i tehnologii tvarynnyctva, 144: 225-232.

KOVALYSHYN, S. and DADAK, V. 2016. Investigation of the separation of impurities of hard-to-divide weed seeds from seed mixtures of cereal grasses [in Ukrainian: Дослідження процесу відділення домішок важковідділюваних бур'янів із насіннєвих сумішей злакових трав]. Visnyk of Lviv National Agrarian University: Agroengineering Research, 8: 20-24.

KOVALYSHYN, S., DADAK, V. and SOKOLYK, V. 2014. Ways of improvement of post-harvest prepation of small seeded cultivated plants. Motrol: Motorization and power industry in agriculture, 16D: 38-44.

KOVALYSHYN, S., SHVETS, O., GRUNDAS, S. et al. 2013. Use of the electro-separation method for improvement of the utility value of winter rapeseeds. International Agrophysics, 27: 491-494.

MOLENDA, M., HORABIK, J. and GROCHOWICZ, J. 1995. Friction of wheat grain. Acta Agrophysica, 4: 85-90.

MOLENDA, M., TOMPSON, S. and ROSS, I. 2000. Friction of wheat on curraged and smooth galwanized steel surfaces. Journal of Agricultural Engineering Research, 77(2): 209-219.

OVSYANNIKOVA, L., ORLOVA, S. and SOKOLOVSKA, O. 2009. Comparative analysis of small-seeded cultures on the basis of statistical characteristics of their sizes. [in Ukrainian: Порівняльний аналіз дрібно насіннсвих культур на основі статистичних характеристик їх розмірів]. The team sciences works Odesa NAT, 36(1): 121-126.

TARASENKO, A. and MYRONENKO, D. 2009. The dependence of wheat seed quality on the frictional properties of the individual grains [in Russian: Зависимость качества семян пшеницы от фрикционных свойств отдельных зерновок]. Vestnic Voronezskoho hos. agro. un, 4(23): 20-23. 
TARUSHKIN, V. 1987. Improving the process of seed separation [in Russian: Совершенствование процесса сепарирования семян]. Mechanization and electrification of agriculture, 3: 36-41.

TARUSHKIN, V. 1987. Modern seed separators [in Russian: Новые сепараторы семян]. Mekhanizatsiya $i$ elektrifikatsiya selskoho khoziaistva. Elektrosnabzhenie, elektroprivod i elektrotekhnolohiya, 12: 3-10.

UKRAINIAN STATE STANDARDS. 2010. Seeds of plant species: vegetables, hippocastanaceae, fodderand intoxicatingaromatic. Varietal and sowing quality [in Ukrainian: Насіння овочевих, баштанних, кормових і пряно-ароматичних культур. Сортові та посівні якості]. DSTU 7160. Kyiv.

ZAIKA, P. 2006. Theory of agricultural machines. Seed cleaning and separation, 3(7): 25-30.

YUNUSOV, R., MUSTAFIN, M., NIZAMUTDINOV, A. et al. 2001. Mechanized production line for seed treatment [in Russian: Механизированная поточная линия для обработки семян]. RU2173586, Russia.

ZAIKA, P. and MAZNEV, G. 1988. Seeds separation by thr complex of physical and mechanical properties [in Russian: Сепарация семян по комплексу физико-механических свойств]. Moscow: Kolos.

ZARE, D., BAKHSHIPOUR, A. and CHEN, G. 2013. Physical properties of cumin and caraway seeds. International Agrophysics, 27(4): 231-244. 